УДК 373.5.016:811.111]:159.955

\title{
ENGLISH LANGUAGE INSTRUCTION FOR CLIP THINKERS
}

\author{
Maryna Tsehelska \\ Криворізький державний педагогічний університет \\ Kryvyi Rih State Pedagogical University \\ пр. Гагаріна, 546 Кривий Ріг, $50086 б$ Украӥна \\ mtsehelska4@yahoo.com
}

Цегельська М. Стратегія навчання англійської мови $з$ урахуванням особливостей кліпового мислення учнів

У статті йдеться про те, що поява сучасних технологій кардинально змінила сприйняття людини $\mathrm{i}$ вплинула на розвиток кліпового (фрагментарного) мислення в підростаючого покоління. Акцентовано, що відповідний тип мислення протиставляють лінійному і що розвиток обох типів необхідно враховувати при сучасному плануванні й розробці матеріалів. Для цього процес навчання повинен бути структурований за когнітивною моделлю обробки знань, інформацію необхідно представляти візуально, а тексти для читання повинні бути креолізовані, містити відразу кілька моделей, які утворюють додаткові смисли.

Ключові слова: кліпове (фрагментарне) мислення, лінійне мислення, методи, що враховують кліпове мислення, фази навчання, креолізовані тексти.

Цегельская М. Стратегия обучения английскому языку с учетом особенностей клипового мышления учащихся

В статье акцентируется внимание на том, что появление современных технологий кардинально изменило восприятие человека и повлияло на развитие клипового (фрагментарного) мышления у подрастающего поколения. Такое мышление противопоставляют линейному, а развитие обоих типов мышления необходимо учитывать при современном планировании и разработке материалов. Для этого процесс обучения должен быть структурирован по когнитивной модели усвоения знаний, информацию необходимо представлять визуально, а тексты для чтения должны быть креолизированы и содержать сразу несколько моделей, создающих смысл.

Ключевые слова: клиповое (фрагментарное) мышление, линейное мышление, методы, учитывающие клиповое мышление, фазы обучения, креолизованые тексты. 
Tsehelska M. English language instruction for clip thinkers

The advent of modern technologies has dramatically changed human perception and influenced the development of clip (fragmented) thinking in younger generation. Fragmented thinking reflects various properties of objects without taking into account relations between them. Clip thinking is contrasted with linear model, which is characterized from operational point of view by linear thinking. It helps to put in order the already acquired knowledge and operate with it at a higher level.

As both ways have their advantages and disadvantages, they have to be taken into account in up-to-date planning and materials development for language teaching. For this materials have to be compiled in a brain-friendly manner as the information has to be constantly reviewed and recycled. The process of learning has to be structured on the cognitive model of knowledge processing, which is based on the four phases of learning - impressing, memorizing, authorization and initiation. They take into account the neurophysiological mechanisms of human perception and allow building robust constructions in the brains of language learners, from where the information can be easily accessed.

Information has to be presented visually and texts for reading need to be creolized and contain several meaning making models at once. The interaction between visual and verbal parts in creolized texts becomes a basis for the transmission of meaning. Such clip thinking considering teaching tools will greatly enhance the perception of language learners and lead to the development of linear thinking in clip thinkers.

Keywords: clip (fragmented) thinking, linear thinking, clip thinking considering methods, phases of learning, creolized texts.

Introduction. With the advent of technologies in the $21^{\text {st }}$ century the ways of perceiving and processing information have changed dramatically. The uses of gadgets and exposure to the mass media world from the early childhood have influenced the development of "clip thinking" or "clip perception" [Platonova / Платонова $2015:$ 778]. The big proportion of clip thinkers in a classroom results in the mass syndrome of attention deficit disorder and loss of interest to new knowledge, which many teachers are now complaining of.

Though English language curriculum for secondary schools in Ukraine has undergone tectonic changes since 1990's, many educators are dissatisfied with the low level of students' knowledge blaming for it outdated textbooks and ways of teaching. Today Ukraine ranks 43 place in the world in English skills [7], and official statistics shows that in 201810638 students failed the External Independent Testing in English, which makes 13\% out of all test- 
takers [2]. No doubt that these results are partially caused by the use of out-of-date textbooks and low teaching skills of the educators, but we also need to take into account cognitive skills of learners, how information is perceived and processed by them.

In this article we'll briefly overview the existing challenges in the English language instruction caused by the growing number of clip thinkers in a language classroom and suggest ways for dealing with them.

Drift from traditional teaching to communicative approach. Teaching English as a Foreign Language changed its paradigm in the second half of the $20^{\text {th }}$ century, when educators shifted from teaching grammar, vocabulary lists and translating sentences to the development of speaking skills. The Communicative Approach aims at the development of communicative competence (the term was coined by Dell Hymes in 1966). It implies that students are able to produce well-formed utterances to achieve their communicative intention in various speech acts. In Ukraine, where English has become as indispensable part of a secondary school curriculum, the implementation of the Communicative Approach had long been hampered with the outdated Ukrainian textbooks and unaffordability of modern textbooks.

With the introduction of New Ukrainian School and the involvement of British Council into the English language curriculum building and preparation of teachers, such textbooks as "My Pal", "Quick Minds" and "Smart Minds" became more accessible and are wider used in primary and basic school [Redko / Редько 2018 : 374]. However, many teachers still complain about the low results of their students, their lack of interest and attention deficit disorder. As the low level of attention can no longer be explained by the absence of textbooks and lack of teaching skills, we may take into account the changing patterns of thinking and perception that modern educators have termed "clip thinking" or "clip perception" [Volkodav / Волкодав 2017 : 374].

Clip thinking as a present-day challenge. Clip thinking which has become a problem of modern education, developed in humans as a result of unlimited use of gadgets, conscious or unconscious intake of mass media and various kinds of social nets. 
Clip thinking or fragmented thinking is regarded as a process of reflecting a multitude of various properties of objects, without taking into account the relationships between them, characterized by fragmented information flow, illogicality, heterogeneity of incoming information, high speed of switching between fragments of information as well as the lack of a holistic perception of the surrounding world [Volkodav / Волкодав 2017 : 376].

The excessive use of gadgets in everyday life is coupled with computerization of education, which is often seen as innovation and a panacea for all problems in teaching and learning. Today we see both educators and learners mastering their user computer skills, which often creates an illusion of access to cognitive actions. However, if the computer skills are not accompanied by the development of thinking skills (from lover order thinking skills to higher order thinking skills), mastering of subject areas and broad cultural perception, they rather complement the development of clip thinking than general cognitive skills.

Clip thinking is often contrasted with linear model, which is characterized from operational point of view by a linear thinking. This type of thinking helps to put order the already acquired knowledge and to operate with it at a higher level [Bratianu / Братіану 2009 : 356].

Both ways of thinking have their positive and negative sides. Linear thinking is responsible for higher order thinking skills that allow processing information deeply, analyzing it and making logical conclusions, building assumptions and theoretical constructs and, as result, getting deeper knowledge. Clip or fragmented thinking speeds up information processing, appeals to the emotions and not to the rational part of our conscious but does not allow making long-term analytical deductions. It brings us to the conclusion that both ways of thinking should be taken into account in up-to-date lesson planning and materials development.

Course planning and materials development. As it has become evident, a modern educator has to take into account clip or fragmented thinking of their students and aim at developing their liner thinking. It means that traditional ways of teaching have to be enhanced with clip thinking considering methods. They have to 
consider the ways of students' perception and add some elements to the activities.

For this, the following elements will be of great use:

1. Materials for learning have to be compiled in a brain-friendly manner that takes into account the outcomes of cognitive linguistics and pedagogy.

2. Information has to be reviewed and recycled taking into consideration the cognitive model of knowledge processing that was developed by M. Karpenko [Karpenko / Карпенко 2008 : 3] as traditional ways of lecturing and testing are not sufficient enough for modern students.

3. Information needs to be presented visually, as visuals have already become a new global language, understood without words.

4. Texts for reading have to be creolized. A creolized text contains several meaning-making modes at once. Interaction of visual and verbal parts of creolized text is termed "meanings arithmetic" since being the basis for the transmission of meanings different from those conveyed through non-verbal and verbal constituents when they are considered separately [Rosen / Розен 2007 : 272].

Language input and recycling. Most traditional language teaching methods suggest giving information to language learners in small amounts, with up to 10 vocabulary units per lesson. These are high frequency words that are often met in speech. Though very useful to language learners, many of them remain unattended as they do not fall into meaningful categories that help our brain organize the material.

This approach may be enhanced with the change of vocabulary input strategies when vocabulary is grouped into concept maps. Such maps present meaningful interdependent categories, which actually clip or fragment the language to make it more comprehensive for language learners. For example, categories for learning about advertisements would be types of ads, media where ads are presented, target audience, reasons and tricks for advertising. These categories aim at clipping the vocabulary of the topic and creating meaningful connections between the categories. 
We have to take into account that visual representation of information assists greatly in language acquisition. It is advisable to illustrate language material with pictures, to colour categorized vocabulary differently and to systematically use pictograms for presenting various parts of speech.

After a concept map is built, it becomes a part of general language learning, that is most effectively built on the cognitive model of the phases of the knowledge processing was developed by M. Karpenko, who defined the interdependence between the neurophysiological mechanisms and the principles of curriculum building, which should take into consideration four phases impressing, memorizing, authorization and initiation [Karpenko / Карпенко 2008 : 43].

The first phase called "impressing" allows building the schematic neuronet in the brain and forms the motivation to learning. At this stage we can only give the scheme of the topic we are going to teach. The students are introduced to the concept maps, overview the categories and find connections between them.

At the second stage a new neuronet is being formed with the help of various exercises, listening and watching films, working with computer programs, etc. At this stage the focus shifts to language, students give deliberate attention to language features and process language deeply. Vocabulary may be taught in non-authentic language tasks to ensure sufficient vocabulary knowledge. Students work at analyzing the grammar of the unit, paraphrase, find synonyms and antonyms. Such activities allow raising language awareness by increasing vocabulary size, improving the use of sophisticated vocabulary, increasing speed access to words and developing strategic competence. At this stage, creolized texts may assist in perceiving and memorization of information. They are made of two constituents - verbal and non-verbal. These two constituents do not act separately - they assist each other in the interpretation of the information and help clip thinkers comprehend better.

The third stage - authorization will edit the neuronet in the brain and at this stage we can start asking students to display the knowledge they got by making presentations, giving talks, reports or participating in the seminars. The tasks at this stage are to be 
oriented at developing such thinking stills as categorizing, comparing, finding cause and effect and overviewing advantages and disadvantages. At the fourth stage the official representation of knowledge is relevant - it is the time for tests and grades [3, c. 167].

Thus, instead of learning fragments of the language and being asked to compile them into a meaningful whole, students of English may get a topic map, where the categories are interrelated, and, through the phases of learning, master the vocabulary and grammar of the lesson.

Conclusion. Recent changes in students' perception insist that teachers should be prepared for the increasing number of clip thinkers in a language classroom. It makes us recognize the necessity of adapting language instruction to the needs of clip thinkers. This adaptation includes, but is not limited to the compilation and presentation of material with the help of both visual and verbal tools, creolization of texts for reading and curriculum building with the consideration of the learning phases. These measures will attend to the development of both types of thinking - fragmented and linear and will greatly contribute to not only language acquisition but to the students' general development.

\section{Література}

1. Карпенко М. П. Телеобучение. Москва : Современная гуманитарная академия, 2008. $800 \mathrm{c}$.

2. Підсумки 3НО-2018.Український центр оцінювання якості освіти. URL : http://testportal.gov.ua/wp-content/uploads/2018/08/ZVIT-ZNO_2018-Tom_1.pdf (дата звернення: 25.03.2019)

3. Редько В. Г., Козлова А. І., Ніколаєнко В. В., Кодалашвілі О. Б. Новій українській школі - компетентнісно орієнтовані підручники: концептуальні засади змісту і структури підручника з англійської мови для 1 класу "MyPal”. Проблеми сучасного підручника. 2018. С. 372-385.

4. Bratianu C., Vasilache S. Evaluating linear-nonlinear thinking style for knowledge management education. Management \& Marketing. 2009. № 4. P. $354-$ 362. URL : https://www.researchgate.net/publication/46542890_Evaluating_linearnonlinear_thinking_style_for_knowledge_management_educationï (accessed: 25.03.2019)

5. Rosen L. D. Me, My Space and I: Parenting the Net Generation. Palgrave Macmillan, 2007. 272 p.

6. Platonova J. Tarasova E., Golubinskaya A. (2015). Creolized Text as a form of Modern Educational Discourse. Procedia. Social and Behavioral Sciences. 
№ 214. P. 788-796. URL : https://www.researchgate.net/publication/287157971 Creolized Text as a form of Modern Educational Discourse (accessed: 25.03.2019)

7. The world's largest ranking of countries and regions by English skills. URL : https://www.ef.se/epi/ (accessed 25.03.2019)

8. Volkodav T., Semenovskikh T. Dichotomy of the "Clip Thinking" Phenomenon. International Conference on Education, Psychology and Social Sciences. Bangkok, 2017. P. 218-221. URL : https://www.researchgate.net/ publication/320225378_Dichotomy_of_the_'Clip_Thinking'_Phenomenon

\section{References}

1. Karpenko M. P. Teleobucheniye. Moskva : Sovremennaya gumanitarnaya akademiya, 2008. $800 \mathrm{c}$.

2. Pidsumky ZNO-2018. Ukrainskiy Tsentr Otsiniuvannia yakosti osvity. URL : http://testportal.gov.ua/wp-content/uploads/2018/08/ZVIT-ZNO_2018-Tom_1.pdf (accessed: 25.03.2019)

3. Redko V. G., Kozlova A. I., Nikolaenko V. V., Kodalashvili O. B. Noviy ukrainskiy shkoli - kompetentistno orientovani pidruchnyki: kontseptualni zasady zmistu I struktury pidruchnyka z angliyskoi movy dlia 1 klasu "MyPal". Problem suchasnogo pidruchnyka. 2018. C. 372-385.

4. Bratianu C., Vasilache S. Evaluating linear-nonlinear thinking style for knowledge management education. Management \& Marketing. 2009. № 4. URL : https://www.researchgate.net/publication/46542890_Evaluating_linear-nonlinear thinking_style_for_knowledge_management_educationï (accessed: 25.03.2019)

5.Rosen L. D. Me, My Space and I: Parenting the Net Generation. Palgrave Macmillan, 2007. 272 p.

6.Platonova J. Tarasova E., Golubinskaya A. (2015). Creolized Text as a form of Modern Educational Discourse. Procedia. Social and Behavioral Sciences. № 214. C. 788-796. URL : https://www.researchgate.net/publication/287157971 Creolized_Text_as_a_form_of_Modern_Educational_Discourse (accessed: 25.03.2019)

7.The world's largest ranking of countries and regions by English skills. URL : https://www.ef.se/epi/ (accessed: 25.03.2019)

8.Volkodav T., Semenovskikh T. Dichotomy of the "Clip Thinking" Phenomenon. International Conference on Education, Psychology and Social Sciences. Bangkok, 2017. P. 218-221. URL : https://www.researchgate.net/ publication/320225378_Dichotomy_of_the_'Clip_Thinking'_Phenomenon 